\title{
Identification of Homestay in Ubud Tourism Area and Peliatan Village Based on Asean Homestay Standard
}

\author{
Ida Ayu Kalpikawati ${ }^{1}$, Ni Wayan Chintia Pinaria ${ }^{2}$, I Gusti Agung Febrianto ${ }^{3}$ \\ \{idakalpika@yahoo.com $\left.{ }^{1}\right\}$
}

Sekolah Tinggi Pariwisata Nusa Dua Bali, Jl. Dharmawangsa, Benoa, Kec. Kuta Sel., Kabupaten Badung, Bali, Indonesia ${ }^{123}$

\begin{abstract}
The construction of a homestay is a priority of the Ministry of Tourism because the Ministry of Tourism has a target of 20 million foreign tourist visits to Indonesia in 2019. Ubud is one of the most famous tourism areas in the world and is one of the growth centers of homestays in Bali. But most homestays in Ubud do not meet homestay standards according to Asean Homestay Standards. This study aims to determine the number of homestays in the Ubud tourism area seen from homestay owners living with tourists, the number of rooms, and facilities owned in accordance with the ASEAN Homestay Standard. The object of this research is all homestays located in Ubud and Peliatan Village, Gianyar-Bali, spread across 22 Banjar. The data analysis technique uses descriptive analysis techniques. Based on the results of the study found from 287 homestays only 115 homestays that homestay owners live together with tourists (guest) and the maximum number of commercialized rooms is 4 rooms according to the ASEAN Homestay Standard. It is necessary to regulate homestay business permits so that homestay businesses in the region Ubud tourism truly provides equitable economic benefits and increases local income. The construction of a homestay that is not controlled will have an impact on increasing competition among homestay owners, reduced green land, causing environmental damage and affecting regional spatial planning.
\end{abstract}

Keywords: Homestay; Tourism Area; Asean Homestay Standard

\section{Introduction}

One type of accommodation that is being prioritized by the Indonesian Tourism Ministry is the construction of homestays. The Ministry of Tourism is targeting the construction of 100,000 homestay units in 2019. Homestay is a development priority of the Ministry of Tourism because the government has a target of 20 million foreign tourist arrivals in 2019 so that tourism facilities are needed in the form of accommodation. Through the construction of a homestay, the government hopes that local residents of homestay owners can immediately enjoy the impact of tourism, especially in terms of the economy. Homestay or better known as a tourist lodge is a lodging business for the general public or tourists by using a portion of the residence of the homestay owner. In addition to being quite economical in terms of price, when tourists are staying at a homestay they may interact directly with the local community so that tourists often consider the homestay they are making a place to stay as a family while visiting a destination.

Ubud is one of the growth centers of homestays in Bali. The potential of nature, especially rice fields, art, traditions of the people, traditional markets, Balinese culinary 
specialties and the existence of the Ubud castle are the main attractions of tourists visiting Ubud. Based on information from the Head of the Tourism Destination Division of the Gianyar Regional Tourism Office, tourists visit to Ubud increase every year. The increase in the number of tourists is directly proportional to the increase in the number of homestay accommodations in Ubud. The Chairperson of the Ubud Homestay Association (USHA) said that currently there are 311 homestays in Ubud area. Homestay is growing and developing in Ubud because homestay is an alternative accommodation with cheap price and simple facilities and services that provide opportunities for tourists, homeowners, and surrounding communities to learn from each other's way of life, language and culture. Based on preliminary observations and discussions with the Ubud Homestay Association (USHA) in February 2018 it was discovered that most homestays operating in the Ubud area and Peliatan Village did not meet the homestay standards especially in the number of rooms and the owners were not living in the homestay area. This is not in accordance with the definition of homestay, namely the effort to provide accommodation in the form of residential buildings inhabited by the owner and partially used for rent by providing opportunities for tourists to interact in their owners' daily lives, which are owned by the local community in order to empower the local economy [1] [2]. An almost identical definition is also found in ASEAN Homestay Standard "the standard focuses on the homestay, where guests will stay with the host family and experience every day the way of life and family in both a direct and indirect manner" [3] [4]. In essence, these two definitions emphasize homestay owners living together with tourists.

At present, the Indonesian government has set homestay standards in the form of the Republic of Indonesia's Minister of Tourism and Creative Economy Regulation Number 9 of 2014 concerning business standards for homestay. The regulation including residential buildings, bedrooms, supporting facilities, kitchens. Service aspects include simple service procedures and management aspects including administration, security and safety, and human resources. For the Southeast Asia region a standard has been set by ASEAN organizations that can be used as a guide in developing homestays, namely the ASEAN Homestay Standard which consists of nine criterias including hosts, accommodations, activities, managements, locations, hygiene's, safeties and securities, marketing and promotion and sustainability principles.

\section{Method}

The objects in this study are homestays located in Ubud and Peliatan Village, GianyarBali which are spread across 22 Banjar. The populations in this study were all homestays in Ubud and Peliatan Village, namely 311 homestays. After observing in the field in March 2018, 259 homestays were still in operation, 21 new homestays and 7 homestays were under renovation. The sample in this study uses a census method where all members of the population are sampled. Sugiyono stated that if all samples use members of the population it is said to be saturated sampling. The sample in this study was 287 homestays. Data collection techniques in this study used questionnaires and interviews with homestay owners. While for the data analysis techniques using descriptive analysis techniques. Descriptive analysis technique is a research method by collecting data in detail, in-depth and actual data according to the real findings in the field and then determining solutions in dealing with a problem [5]. 


\section{Discussion}

ASEAN Homestay Standard explains that the homestay is "an alternative tourism place that will stay with the host's family in the same house and will experience the everyday way of family and local community", the understanding explains that homestay is an alternative tourism where tourists will live with the family of the owner of the house in the house and participate in daily life with family and the local community. This study refers to the ASEAN Homestay Standard with the criteria of the homestay to be used, namely the maximum number of rooms for 4 rooms and the homestay owner staying at the same house [2].

Basically, the homestay does not emphasize the commercial element or the search for personal gain, but rather the lifestyle experience and empowers the host family and local community in terms of economy and culture. So what makes a hotel or homestay home different from other similar accommodations is the concept of "home". Its main characteristic is the element of living together with the daily host family, involving tourists eating, cooking, or doing activities together [5]. Become, host family living in a place not just renting out space or buildings that are 'nuanced' at home. Another characteristic is the boundaries between public space and private space. Private space in a house is opened into a public space, different from other accommodations whose private space is only open to staff. As for Rivers in Seubsamarn stated that homestay accommodation utilities and food are usually included, the length of stay can be daily, weekly, or even unlimited weekly unless determined by the homeowner [6].

Ubud is one of the tourism areas in Bali that is very famous among tourists because of its unique culture, nature and rice fields that are still well preserved. Besides having the potential in nature, Ubud is very well known for its friendly hospitality which is a characteristic of Balinese people. This potential causes make Ubud become one of the selected tourism destinations. To support Ubud as one of the tourism destinations various facilities and infrastructure can be found in the Ubud area starting from restaurants, bars, star hotels, budget hotels, villas and homestay.

Based on the results of the study found 271 homestays or 94.43 percent of homestays in the Ubud tourism area that are in accordance with the ASEAN Homestay Standard seen from homestay owners living together with tourists in the sense of homestay while 16 other homestays, homestay owners do not live with tourists. Then when viewed from the number of rooms according to the ASEAN Homestay Standard which is a maximum of 4 rooms (a maximum of four of the total number of bedrooms in the house, which are not being used by any member of the homestay provider/host shall be allocated to homestay guests [2], there are 120 homestays or around 41.81 percent that comply with these standards, 167 other homestays have a number of rooms that exceed the prescribed standards.

Based on ASEAN Homestay Standards, it is explained that homestay owners live together with tourists (guest) and the maximum number of commercialized rooms is 4 rooms. Based on these criteria's, the homestay owner lives with tourists and the maximum number of rooms is 4 rooms. It was discovered that from 287 homestays that were sampled in this study only 115 homestays or 40.06 percent (less than 50 percent) were in accordance with these criteria. Of the 115 homestays, the facilities owned are as follows:

a. 33 homestays provide bedrooms, bathrooms, food and beverage and additional facilities such as a swimming pool.

b. 53 homestays provide bedrooms, bathrooms, food and beverage facilities.

c. 29 homestays provide bedrooms and bathrooms facilities. 


\section{Conclusion}

The results of this study are expected to provide additional information, especially to the local government of Gianyar Regency, to better regulate the issuance of homestay business licenses in the Ubud tourism area in accordance with the requirements of the ASEAN Homestay Standard. With the stipulated conditions, it is expected that the existence of a homestay accommodation business can directly benefit the community in the Ubud tourism area in terms of economic equality, namely increasing the income of local people. When the permit is not regulated, it is possible that the community will build a homestay with a number of rooms that exceed the standard or uncontrolled so that it will have an impact on competition between homestay owners. The difference in the number of significant rooms between one homestay and another homestay will increase competition between homestay owners even more so if the homestay with a smaller number of rooms still uses a simple management system so that it will increasingly be unable to compete. Besides being faced with competition for a number of rooms, homestays are also faced with competition with large hotels which are currently developing in the tourist area of Ubud. Therefore it is important for the government to be firm in giving homestay permits, namely those who have a maximum number of rooms 4 and the owner lives with his guests so that economic equality is created and harmony between communities is still maintained. In addition increasing competition between local communities, the construction of uncontrolled homestays also causes the environment to receive a lot of pressures such as increasing the amount of waste and waste produced which results in a decrease in environmental quality. The decline in the quality of the environment will have an impact on the sustainability of the tourism industry.

\section{References}

[1] Kementerian Pariwisata, Peraturan Menteri Parwisata Republik Indonesia Nomor 18 Tahun 2016. Indonesia, 2016, pp. 1-32.

[2] The Association of Southeast Asian Nations (ASEAN), Asean homestay standard. Jakarta: The Asean Secretariat, 2016.

[3] Asean, "Asean homestay standard," Jakarta, 2016.

[4] Y. Ibrahim and A. Rashid, "Homestay Program and Rural Community Development in Malaysia," J. Ritsumeikan Soc. Sci. Humanit., 2010.

[5] Sugiyono, "Metode Penelitian Pendidikan Pendekatan Kuantitaif, Kualitatif, dan R\&D," Metode Penelitian Pendidikan Pendekatan Kuantitaif, Kualitatif, dan R\&D. 2013.

[6] K. Seubsamarn, "Tourist motivation to use homestays in Thailand and their satisfaction based on the destination's cultural and heritage-based attribute," University of Missouri, 2009. 